Abstract Deadline: Friday, December 13, 2013, 11:59 PM EST

To submit your abstract, visit www.aats.org/aortic

Authors submitting abstracts for the AATS Aortic Symposium 2014 must use electronic submission ONLY. Visit the AATS Aortic Symposium 2014 Web site at www.aats.org/aortic and select the Submit Abstract link. Specific instructions for abstract submission are located on the Web site, including how to submit graphs or charts.

The American Association for Thoracic Surgery is accredited by the Accreditation Council for Continuing Medical Education to provide continuing medical education for physicians.

This activity has been approved for AMA PRA Category 1 Credits $^{\mathrm{TM}}$.

\section{AATS Leadership Academy}

Friday, April 25, 2014, Toronto, Canada

(Held immediately prior to AATS Annual Meeting)

\section{Applications Now Available: November 30th Deadline}

The 2014 AATS Leadership Academy is an intensive, didactic, and interactive program for up to 20 surgeons who have concluded their residency and been in an academic appointment for no more than three years or will be finishing their residency in 2014 and starting an academic appointment upon its conclusion. Interested applicants should meet the following qualifications:

- Active North American surgeon

- Completed residency and been in an academic appointment for no more than three years or will be completing residency in 2014 and starting an academic appointment upon its conclusion.

- Evidence of academic and leadership accomplishments.

- Letters of support outlining the applicants benefits of participation in the program.

- Personal statement outlining future career goals

Applications for consideration must be submitted electronically at www.aats.org by November 30, 2013. Participants will be selected by the Leadership Academy Committee and notified no later than February 5, 2014.

\section{AATS Summer Intern Scholarship Applications Now Available}

The AATS Summer Intern Scholarship program introduces the field of cardiothoracic surgery to first- and second-year medical students from North American medical institutions. By providing an opportunity to spend 8 weeks during the summer working in an AATS member's cardiothoracic surgery department, the summer intern scholarship presents medical students with insight into the scientific investigation and study of cardiothoracic surgery.

A grant of $\$ 2,500$ is provided to successful applicants to underwrite their living expenses during the 8 weeks of guidance at the selected host institution. Additionally, all awardees will receive complimentary registration to the Association's 2014 Annual Meeting and postgraduate courses taking place April 26-30, 2014, in Toronto, Canada.

For more information and to submit an application, please visit the AATS Web site at www.aats.org. Application Deadline: January 15, 2014.

\section{AATS Applications for Membership Now Available Online}

Applications for membership in the Association are now available online at www.aats.org. Interested applicants are encouraged to consult with current active or senior members of the Association and to review the membership requirements and guidelines on the AATS Web site.

To apply for membership, a current member of the Association must act as the primary sponsor by initiating the application process in the Members Only area of the AATS Web site. Applications must be received by November 30, 2013, for consideration. All applications received after that deadline will be automatically deferred until November 2014.

\section{The Western Thoracic Surgical Association}

\section{Applications for Membership}

The WTSA is now accepting Applications for Membership online for Active as well as Candidate membership status. Visit the WTSA Web site at www.westernthoracic.org to read the complete membership eligibility requirements and to initiate an online application.

\section{Active Member}

$\$ 325.00$ annually, plus $\$ 50.00$ initiation fee 